\title{
Ampulla of Vater Cancer pNO TNM Finding v7
}

National Cancer Institute

\section{Source}

National Cancer Institute. Ampulla of Vater Cancer pNO TNM Finding v7. NCI Thesaurus. Code $C 90276$.

Ampulla of Vater cancer with no regional lymph node metastasis. (from AJCC 7th Ed.) 